\title{
Voluntary Work in Digital Contexts as Gift Exchange
}

\author{
Caroline Ruiner (D)
}

\section{check for} updates

Citation: Ruiner, C. Voluntary Work in Digital Contexts as Gift Exchange. Sustainability 2021, 13, 12176. https:/ / doi.org/10.3390/su132112176

Academic Editor: Mariarosaria Lombardi

Received: 17 September 2021 Accepted: 1 November 2021 Published: 4 November 2021

Publisher's Note: MDPI stays neutral with regard to jurisdictional claims in published maps and institutional affiliations.

Copyright: (C) 2021 by the author. Licensee MDPI, Basel, Switzerland. This article is an open access article distributed under the terms and conditions of the Creative Commons Attribution (CC BY) license (https:// creativecommons.org/licenses/by/ $4.0 /)$.
Institute for Education, Work and Society, University of Hohenheim, 70599 Stuttgart, Germany; caroline.ruiner@uni-hohenheim.de

\begin{abstract}
Digital technologies have inspired a change in volunteering in nonprofit organizations. In this context, the engagement of volunteers is mainly self-organized, through online platforms or apps. It is the aim of this paper to analyze the volunteers' motives, differentiating between self-interest and other-interest. This is important, since effects on organizational volunteer-related outcomes, such as volunteer engagement, recruitment and retention, are likely to occur. A gift exchange perspective is applied and a case study has been used for investigating an online-based nonprofit organization in Germany, consisting of qualitative interviews with experts and volunteers, documentary analysis and participatory observations as well as an online survey. The results show that the volunteers' instrumental self-interest in gaining food, and their interests in other factors, such as the reduction of food wastage as a societal goal, occur simultaneously. This leads to paradoxes and problems on the organizational level. This study contributes to understanding volunteer engagement, recruitment and retention in digital nonprofit organizations.
\end{abstract}

Keywords: gift exchange; nonprofit organization; reciprocity; volunteer engagement

\section{Introduction}

Digital technologies have inspired a change in volunteering in nonprofit organizations. In this sense, the engagement of volunteers is mainly self-organized through online platforms or apps. The use of digital technologies exemplifies the ability of the nonprofit sector to create new relationships among different actors to achieve societal goals [1]. It shows differences from other volunteer-based organizations (i.e., less personal contact), and the volunteering opportunities are more suited to a self-interested type of volunteer. This is expected to change the relationship between volunteers and nonprofit organizations $[2,3]$. In particular, the gift exchange perspective is applicable to understanding this development, since it refers to a reciprocal exchange of two parties considering altruism and egoism [4-6]. It is the aim of this paper to analyze the volunteers' motives, differentiating between self-interest and other-interest.

The empirical data are based on a case study [7] of an online-based nonprofit organization in the German food sector, consisting of qualitative interviews with organizational representatives and volunteers $(n=15)$, documentary analysis of homepages and internal manuals, participatory observations of food collections as well as an online survey with volunteers $(n=314)$. The results show that self-interest in gaining food and other interests, such as the reduction of food wastage as a societal goal, are both relevant. This simultaneous occurrence of altruistic and egoistic motives leads to paradoxes and problems on the organizational level.

This paper makes three conceptual contributions: this study (1) emphasizes that altruistic and egoistic motives of volunteers occur simultaneously, and (2) illustrates the interrelation between the individual and the organizational level. Finally, the study (3) contributes to understanding organizing volunteer engagement with the help of digital technologies.

The paper is arranged as follows: in the next chapter, the perspective of volunteering in nonprofit organizations from a gift exchange perspective will be introduced. After presenting the case study approach in the methods section, the results will be outlined. 
This paper ends with a general discussion, summarizing the findings, explicating the conceptual contributions and practical implications as well as pointing to limitations and outlining perspectives for further research.

\section{Conceptual Framework}

\subsection{Volunteer Work in Nonprofit Organizations from Gift Exchange Perspective}

Generally, volunteering is defined as "the unpaid help provided in a structured way to entities or causes [to] whom the worker has no 'formal' obligations. Thus, a volunteer contributes with his or her talent, time and energy to help individuals, groups, communities or organizations without financial compensations" [8]. In this definition, it is essential that volunteers do not receive money for their engagement. Thus, volunteering is based on altruism, requiring free will, lack of financial gain, and benefit to others [9]. However, relationships between volunteers and the organization are characterized by reciprocal benefits [10,11]. Obviously, this could also imply egoistic motives, such as competence development, networking or gaining material benefits. McAllum [12] emphasized that individuals weigh up the costs and benefits of volunteering, which is critical to engage and retain volunteers as they make a rational, uncoerced choice to volunteer [13]. Costs include physical resources and time [14], while benefits result from fulfilling interests, and needs [15]. Consequently, the weighing up of costs and benefits is decisive to volunteers and their engagement in nonprofit organizations.

This is especially critical in digital contexts where opportunities for volunteering are based on self-organization [16-22]. Digitalization in the form of online platforms and apps facilitates the coordination of individual tasks and contributions. In this context, the nature of the relationship between volunteers and nonprofit organizations changes, since contacts are less personal and self-interest is promoted [2]. This also directly affects the nonprofit organizations' opportunities to recruit and retain volunteers.

To understand relationships between two parties as exchange relationships, Mauss [5] conceptualized the reciprocal giving and taking of people as gift exchange. This perspective is helpful to understand volunteer engagement because it considers both altruism and egoism. A constitutive element of this perspective is that benefits and compensations take place in a voluntary form through gifts although they are basically strictly mandatory. Mandatory means that gifts range between voluntariness and social obligation. In this sense, only the first gift is voluntary as the following gifts are exchanged based on reciprocal norms. Gifts also have a symbolic function, i.e., the gift acquires its meaning through its utility and exchange value as well as through the symbolism attributed to it, which clarifies the relationship between those who exchange as part of the gift exchange. Godbout and Caille [4] further developed Mauss' approach and locate gifts between a total of four poles. He distinguished between the motives of obligation and freedom as well as self-interest and interest in others. These four dimensions are closely interwoven. "Self-interest" is a rather instrumental, economic interest, e.g., in the disposal of resources; "interest in others" refers to a higher aim and leads to selfless actions.

With regard to nonprofit organizations, already Cnaan and Goldberg-Glen [23] discussed that volunteers have both altruistic and egoistic motives and emphasized that volunteers not only give but they also receive some type of reward or satisfaction. Schervish [11] analyzed the relation of giving and volunteering and revealed the social effects or outcomes of altruism. Moreover, MacNeela [10] investigated the give and take of volunteering and showed that volunteer motives, personal connections to organizations and causes, benefits and challenges arising from volunteering are decisive factors for volunteer work. Further, other-oriented and self-oriented motives can be differentiated in the context of volunteer work [24]. In particular, other-oriented motives were positively correlated with satisfaction and intentions to continue engagement [25]. Others argued that altruism but not utilitarian motives had effects on volunteering [26]. These findings highlight that altruistic as well as non-altruistic motives are relevant for volunteers but, so far, their relationship remains ambiguous. Consequently, regarding the constitutive weighing of costs and benefits of 
volunteering, the perceptions of those involved of the (balance of) benefits and rewards are central. Against this background, it can be assumed that the reciprocal relationship between giving and taking is essential for understanding volunteer engagement, especially when volunteering is based on self-organization via digital devices.

\subsection{Digital Nonprofit Organizations in Food Sector}

The use of digital technologies is especially relevant in the context of perishable goods. In this sense, the high amount of food wastage [27] has inspired the use of digital technologies to mobilize volunteers for nonprofit organizations in the food sector. Previous research points to the scalability, flexibility, and potential for high-speed exchange, which makes digital sharing platforms well-suited for the exchange of perishable food items; studies have also analyzed the sustainability and environmental impacts of peer-to-peer food exchanges with regard to, for example, carbon opportunity costs [18]. Digital nonprofit organizations allow the redistribution of surplus food, such as OLIO or Too Good To Go as organizations, who have identified the economic, environmental, societal and political outcomes $[19,20]$. Harvey, Smith, Goulding and Illodo [17] focused on OLIO to analyze this peer-to-peer technology, which is supporting the prevention of food wastage. The assumption of generalized reciprocity as relevant in the sharing economy is challenged as inadequate [28]. Rather, the donor-recipient reciprocity and balance are rare, and novel social relations have formed between organizations and individuals. Morrow [21] examined the act of self-organizing in community food initiatives to decentralize and democratize the logistics and redistribution of food through peer-to-peer gifting and community fridges. In this sense, governance strategies have developed to manage food as a common area of interest [22]. Davies, Cretella and Franck [16] analyzed food sharing initiatives based on digital technologies as a potential means to enhancing urban food democracy, as participation, the right to food, sustainability, and reorienting control. They argue that initiatives are particularly challenged in the regulated sector of food safety to reach their goals. It is also emphasized how sharing practice is integrated into the market and how this is aligned with other value regime elements, namely governance mechanisms and higher-order values [29,30]. Others investigated in particular the communication between volunteers and emphasize that ecological, social and economic motives are the basis for the individual's engagement [31]. Rombach and Bitsch [32] analyzed the motivation to participate in food movements. On the basis of the analysis of 25 in-depth interviews, they found out that an economic motivation, such as, for example, material profit or savings, were less relevant. Dominant motivations were instead ecological, such as reducing food wastage, and social, such as the motivation to help others. Adding to this, Schanes and Stagl [33] showed that food sharing volunteers are motivated by different aspects. Besides ecological and social motives, other motives such as reward and social influence are likewise relevant. So far, it remains unclear how motives affect the volunteers' engagement and the relation between individuals and the organization. In this sense, how these different motives translate into actions and affect organizational volunteer-related outcomes, such as volunteer engagement, recruitment and retention in nonprofit organizations, has not been analyzed yet.

To summarize, the nature of digital nonprofit organizations and self-organized volunteer engagement are of interest because of their striking differences compared to traditional nonprofit organizations that are based on personal contact and obligation. This new type of volunteer organization is expected to change the relationship between individuals and organizations, and, concomitantly, the relevance of different motives. Previous studies pointed to the relation of altruistic and egoistic motives and engagement and it can be expected that volunteer engagement is lower when economic motives are dominant. However, studies also emphasize that ecological, social as well as economic motives are likewise relevant, that altruistic other-interest as well as egoistic self-interest plays a role for volunteers. How this affects the relationship of individuals with nonprofit organizations remains unclear so far. A gift exchange perspective helps in understanding the reciprocal relationship between individuals and organizations in the context of volunteering. In particular, the nonprofit 
organization selected is an interesting example, since this is a dynamic and fast-growing organization based on self-organization through digital technologies, such as an online platform and an app. Thus, this case provides the basis to analyze volunteering from a gift exchange perspective since volunteers contribute to reducing food wastage through taking and consuming food in return for their engagement. In this context, the self-interest of volunteers as well as their interest in others, i.e., the interest to be involved in a good cause and at the same time receive food for free in return, are essential.

\section{Data and Methods}

\subsection{Case Selection}

To analyze the volunteers' self-interested and other-interested motives, a case study design [7] is used and a mixed-methods study design is applied [34], consisting of qualitative interviews with experts and volunteers in Germany, a documentary analysis and participatory observations as well as an online survey. The online-based nonprofit organization was selected as a case since it targets the reduction of food wastage by regularly collecting food from supermarkets and distributing it to people by using an online platform [35]. In this sense, the nonprofit organization is driven by the new (digital) technologies of platforms, providing the basis for a fast and short-term coordination and self-organization of volunteers to engage in the collection of food [16,19-22,29-32,36].

\subsection{Interview Study}

The qualitative study contains 15 semi-structured interviews conducted in 2016 and 2017, having approached a triangulation of perspectives in order to collect the experiences and the perspectives of the people concerned. Eight representatives of the organization were interviewed as well as seven volunteers from six different cities in Germany. The interviewees were recruited through social networks on the internet (e.g., Facebook.de, Foodsharing.de), as well as a notice hung out at local spots, such as public shelves or refrigerators, where food is deposited to be shared. Subsequently, both gatekeepers and the snowball principle assisted in the recruitment of other interviewees. Of the respondents, eight were male and seven were female; the interviewees were between 25 and 55 years old (see Tables A1 and A2). The interviewees had to be engaged with the organization for more than six months to be selected for an interview.

The interview guidelines that were used started with a narrative stimulus such as the following: "Perhaps we can start by telling how it happened that you are engaged in the nonprofit organization". The respondents' experiences with volunteering and their volunteer engagement were addressed, as well as their cooperation with other volunteers, and there was a particular emphasis on questions about the process of exchanging and sharing food. Finally, the further development of the organization and the related opportunities and risks were of interest. The length of the interviews was between 16 and $140 \mathrm{~min}$, and the average was $48 \mathrm{~min}$. The interviewees had the choice of a face-to-face or telephone interview. Altogether, six interviews were by telephone. All interviews were audio-recorded, transcribed, and anonymized.

\subsection{Documentary Analysis}

In addition to the interviews, a documentary analysis [37] was undertaken. More concretely, the homepages of Foodsharing.de and local Facebook groups, as well as internal manuals, were analyzed to understand the basic rules and guidelines of the organization, and the responsibilities and duties of different positions and functions. These were also the documents food-savers need to know to pass an initial test.

\subsection{Participatory Observations}

Moreover, two participatory observations [38] were conducted. The aim was to experience the concrete actions, interactions, and negotiations of volunteers; how and why they collaborate. The two observations of food collections at one supermarket and 
one marketplace were conducted in two different cities; the time taken to conduct each was about one hour. The observation was participatory, open and unstructured. Thus, the subjectivity of the investigator became an integral part of the research process. The field notes were written directly afterwards, focusing on the social situation, the setting and participants, the interactions between volunteers, conversations and the observer's own acting, feeling and thinking. The reflections of the researcher about her actions and observations in the field, her impressions, irritations, influences, emotions, etc., are the basis for interpretations.

\subsection{Qualitative Data Analysis}

The data evaluation relied on qualitative content analysis [39], which is an approach of systematic, rule-guided qualitative text analysis. A deductive application and an inductive development of codes were included. Deductive codes applied to materials were, for example, the organizational structure, the conditions and process of sharing food, and future perspectives. Similarly, inductive categories out of the material were formulated, for example, the creation of structures, regulation of legal matters and compliance with rules. Subsequently, coding rules for the categories were explicated and examples identified. Finally, each code was defined, examples were found, and coding rules were explicated. The coding system was constantly checked and modified, expanded and revised. The final code scheme was applied to all materials and the results were interpreted.

\subsection{Online Study}

Finally, an online survey among volunteers was conducted. The link was shared within the organization, thus addressing the people that received the respective newsletter. Participation in the study was voluntary, thus self-selection processes are expected. The survey took $15 \mathrm{~min}$ and all questions were optional. Questions on the interaction with digital technologies were included and also the autonomy scale of [40]. Moreover, since volunteers emphasized that they find their work intrinsically rewarding in the qualitative study, motivation was included. The scale of Ryan and Deci [41] was applied, and used two items for each motivation type. Finally, besides motivation, work engagement was measured as dependent variable. The scale of Rich, LePine and Crawford [42] was applied and used in a total of six items (two items each for physical, emotional and cognitive engagement). Most constructs were rated with 5-point items of the Likert items type, with scale endpoints ranging from (1) I totally agree to (5) I disagree. The sample group can be specified as follows: respondents $(n=314)$ were predominantly female $(80 \%)$. They were between 20 and 77 years old with a mean of 37 years. Regarding qualification, 56.6\% had an academic degree, $13.5 \%$ graduated from a vocational education, $17.5 \%$ had a high school degree and $12.4 \%$ had other (i.e., lower) degrees. Respondents had volunteered for between one and 128 months, and on average for 28 months. Over $51.5 \%$ carry out their volunteer work several times a week, mostly between three and five hours.

\section{Empirical Findings}

\subsection{The Case}

The nonprofit organization of volunteers was established in 2012. In October 2021, 104,961 members were engaged and approximately 57.668 tons of food have been saved in German speaking countries (i.e., Germany, Austria, and Switzerland). Furthermore, 10,310 companies cooperate with the nonprofit organization [35].

The organization shows the following structure. At the base, there are so called food-sharers, i.e., people who offer to collect and pick up food from peer-to-peer through digital food baskets on online platforms. They can also deposit food at local spots (so called Fairteiler). These are public shelves or refrigerators located in public spheres, such as universities or restaurants, offering food to take to everyone interested. Volunteers partly prefer to distribute food through these publicly accessible shelves to avoid time-intensive coordination via social media. Besides the exchanges between individuals, volunteers 
also pick up surplus food from companies, such as supermarkets. To participate in these food collections, volunteers are required to pass a test on the online platform to make sure that they know the rules (i.e., legal requirements) as well as the organizational philosophy and principles (i.e., refusing money, reliability, and punctuality). After passing the test and having an introductory phase of three food collections at supermarket chains, smaller organic markets, and marketplaces, they are registered as so-called food-savers and can participate, self-organized, at the supermarket food collections. The food collections are planned in such a way that a person responsible posts collection dates on the platform to which food-savers can subscribe to. Then, volunteers go to supermarkets at decreed dates to collect the food that the supermarket has sorted (and would have been wasted), and then they take it home, distribute it among people and institutions interested, or deposit it at local pickup spots. Each supermarket has one person who is responsible for securing the regular food collections. Moreover, ambassadors coordinate regional groups and are responsible for coopting new volunteers and training them. Finally, the organization has a board of directors and an extended board of directors, which are concerned primarily with legal issues, such as contracting with supermarkets, solving problematic situations in local groups and communicating in a corporate manner.

\subsection{Volunteering as Gift Exchange-Investigation of Volunteer Motives}

In the first step, the volunteers' motives to participate in the nonprofit organization and the basis for their engagement will be analyzed. Basically, there are ecological, social and economic motives [31-33]. This has already been outlined by previous research and can also be found in the present study. The motives were addressed in the quantitativeempirical survey, asking about the reasons why they engaged (Figure 1).

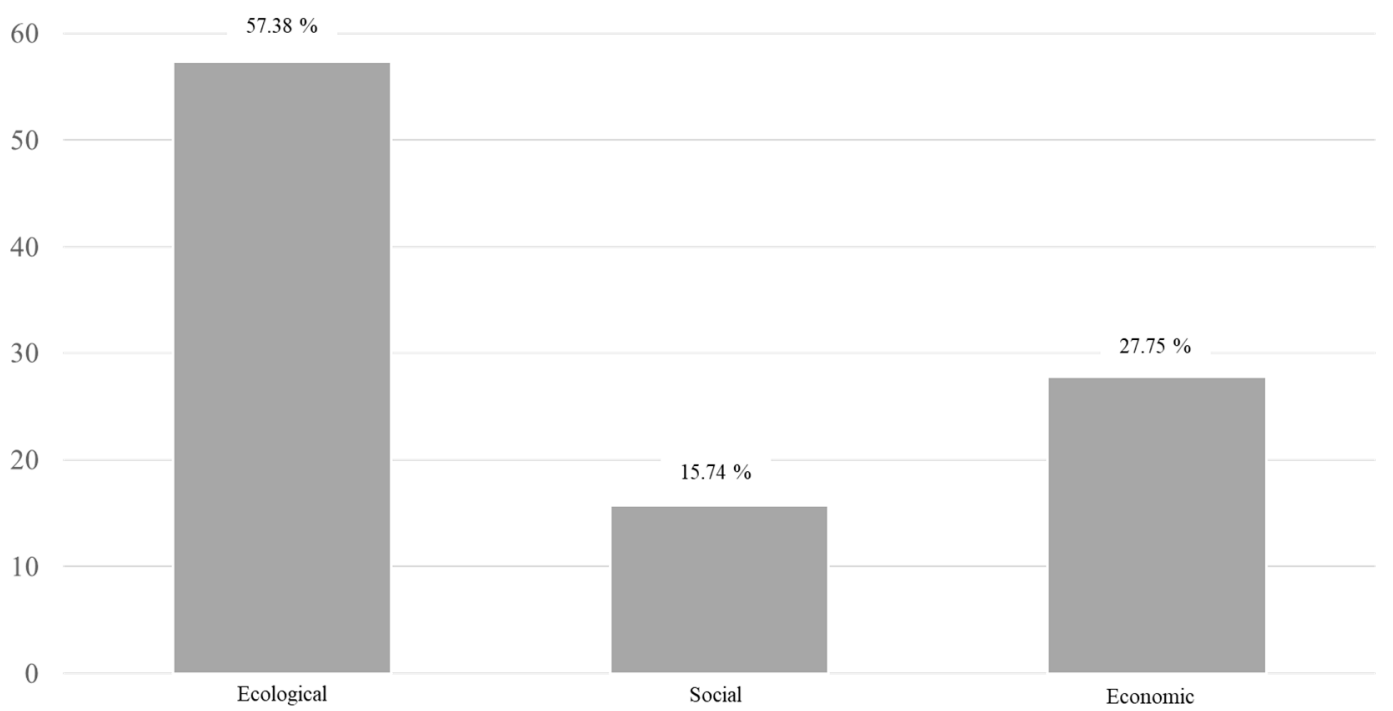

Figure 1. Quantitative Results of Volunteer Motives.

The analysis shows that ecological motives as contributing to societal goals are dominant. Ecological motives refer to the contribution to reducing food wastage, as the following quote illustrates.

"There is the attitude to refuse consumption. And just: We simply cannot accept others do throw food away. It's all about rescuing food." (V3: 39)

Social motives for volunteering focus on meeting people with similar interests, with whom one cooperates to reach a shared goal.

"Of course, you [meet] many like-minded people" (O5: 99) 
However, volunteers also have economic motives. This is particularly related to the fact that the engagement in reducing food wastage implies that volunteers receive food for their own consumption. This has likewise been emphasized by organizational representatives and volunteers.

"I mean you cannot underestimate this, even if we do a lot of things for other people, of course, we also do it for ourselves. You realize the amount of money one saves by consuming food that would have been thrown away. And these things are perfectly fine." (O5: 7)

"If these things would have only been thrown away, it is something where you can do something good and still profit from it. This has been a small reason at the beginning. But, during my first food collection, I realized how much food wastage there is. And what you really can take home. Then the money has become an argument as well. If you go to a food collection and take ten mangos and ten avocados home, it's really worth it.... I am not the type of person who stays ten hours a week somewhere to do something for a good cause. But I think it's cool when you can say, well, that is also for my own advantage and that is just something that nevertheless pays off." (V4: 46ff.)

The relevance of ecological, social, and economic motives is evident. Volunteering contributes not only to the achievement of societal goals, but also creates the possibility of receiving food for free while reducing food wastage. Obviously, different motives are relevant, overlap or are combined. Especially with regard to economic motives, volunteers carefully weigh up and balance their engagement in relation to the food received. The interest in others in the sense of reducing food wastage is weighed against the costs of engagement. Consequently, the occurrence of altruism and egoism impacts volunteer-related outcomes, such as volunteer engagement, recruitment and retention, which condenses into paradoxes and problems on the level of the organization.

\subsection{Individual Motives and Organizational Outcomes}

\subsubsection{Maintenance of Local Spots}

Regarding the relationship between individuals and organizations, the first problem in the participation of volunteers becomes obvious when regarding the maintenance of local spots and the different contributions of members required to keep the organization going. The existence of local spots is useful to support the distribution of the food collected. However, during food collections at supermarkets, for instance, food-savers relate their effort to the benefit:

"And I thought we would bring more food to these local spots, where other people could get it. I actually thought that you do not take so much for yourself. Now I have the feeling, that actually the main thing is that volunteers distribute the collected food among themselves. ... It is just an extra effort. And it is an effort, of which you definitely have nothing, because you bring it to the local spots and that's it." (V4: 46ff.)

In this sense, the self-interest of volunteers might counteract the basic principles and the organizational goal. Another problem is the cleaning of and caring for local spots. It is difficult to find volunteers for this type of work in each of the cities investigated. However, this contribution is necessary to keep the local spots running.

"Of course, we try to solve this, and that is definitely a huge effort with a cleaning plan and so on. That was an official requirement. It is extremely difficult. It is extremely difficult to find volunteers who want to contribute to it. ... If it is not clean, then they shut down the local spots. ... I just say it is not my problem. You all have the advantage of a local spots, then please, also bear the disadvantages." (O5: 87ff.) 
The organization of local spots emphasizes the classic free-rider problem of collective action [43]. It is mentioned that the existence of local spots is an advantage for all, not only because food items can be easily exchanged without time-consuming coordination in advance. It is also the place where large amounts of food can be deposited for collection. In this respect, it would be in the interest of all food-savers to keep the local spots. Their cleaning and care, i.e., removing of food items which have gone off, is critical because of the special requirements of supervisory authorities in some cities and the fact that some local spots have already been closed. The maintenance of local spots calls for the commitment of all, which is perceived as an activity more for the community than for oneself. Here, the extent and type of individual engagement are critical and point to the relevance of balancing self-interest and other-interest to be able to continue and further develop the organization.

\subsubsection{Expansion of the Organization}

Besides the lack of volunteer engagement as exemplified with regard to the caring for local spots, volunteers complain that they cannot engage in food collections at supermarkets to the extent they would like to. It has been critically noted that there were hardly any possibilities for food collections in some cities, or that the scarce possibilities were relatively quickly staffed. Thus, food-savers can participate and contribute only to a limited extent. The number of food collections is based on the premise that the organization only encourages approaching new companies if there are enough people to ensure long-term, regular and reliable food collections to supermarkets, as the following quote exemplifies.

"They can organize everything themselves and they have to, because you can't do that in a central way. They need to, before they go to a supermarket or to a bakery or a vegetable merchant, have the staff to guarantee food collections regularly for a long time. Because you can start cooperation with a supermarket, for example, and they abolish their garbage containers, because they throw away much less. And if we show up and don't show up, this would cause chaos.... Because that was also a great concern of ours to enter this cooperation. And I mean, that is then nationwide, if you pull a large supermarket chain on board, and then it fails in one place, this may mean that it fails for all places, then the management says "no, we do not want to work with this chaotic organization." But this has gone excellently so far. ... By the fact that, basically, we said from the outset, there must be enough people, even in reserve, before such cooperation is initiated, obviously the system works." (O2: 177ff.)

Special occasions, such as semester breaks and holiday periods, are considered because fewer food-savers are available and food collections still have to be guaranteed during these periods. The engagement can be abandoned quickly and self-determinedly.

"Because volunteering is fair enough, but nothing can be abandoned as quickly as an honorary office. And I cannot force anyone to work voluntarily." (O2: 229)

Food-savers could approach new companies, especially if there are so-called responsible persons who are willing to coordinate the food collections, will try to motivate food-savers to join understaffed food collections, and will stand in when things go wrong. The organization could also expand by winning new members. The presence of a critical mass is, above all, highly relevant for the sharing organization, accompanied by a lowthreshold access [44]. In this context, the organization is seen as essential for the volunteers decisions to participate, collaborate and contribute, especially considering the costs and benefits of volunteering.

"I could do this food basket thing that is what the people do alone ... But to go then to the supermarkets is what people do. And this is why it works in the ballpark. And this is what makes sense to me. So, the other thing is nice, if people want to do it, let them do it. I think that's good. ... But to save two or three bananas from the compost, no, the cost-benefit calculation does not 
make sense. The organization makes the difference. ... They organize how many people are needed and they take care that a car is available and facilitate that newbies participate and are introduced.... Well this means the organization is very important. Because this makes the movement so big that it really makes sense. The other thing is also nice, but I think, does not really change a big thing." (V4: 56ff.)

This exemplary quote from a volunteer points to a paradox. The organization is needed as it sets the frame for beneficial volunteer engagement and provides the facilities to collect food. However, the nonprofit organization requires individual engagement not resulting in direct inducements (for example, cleaning of local spots) and this leads to a higher degree of obligations, since they contract with supermarkets and have to secure that there are volunteers to collect the food. The paradoxes and problems result from the co-presence of self-interest and other-interest in volunteer engagement.

\section{Discussion}

\subsection{Summary of Findings}

In the context of digitally organized volunteer work, the aim of this paper was to analyze the volunteers' motives, differentiating between self-interest and other-interest. This is important since it is expected that this affects volunteer-related outcomes, such as volunteer engagement, recruitment and retention. The analysis shows that the volunteers' instrumental self-interest in gaining food, and interest in other factors, such as the reduction of food wastage, occur simultaneously. Accordingly, volunteering is not only about engagement for the purpose of a societal goal, but, as it is in the case investigated here, this is also a possibility to receive food and save money while reducing food wastage. Consequently, volunteers receive a combination of intangible and tangible benefits from their engagement. To reach the aim of reducing food wastage, thus simultaneously achieving organizational and individual goals, is of special relevance. The case study also revealed that the simultaneous occurrence of self- and other-interests leads to paradoxes and problems on the organizational level. The relationship between volunteers and organizations can be conceptualized as outlined in Figure 2: The organization pursues the societal goal of reducing food wastage [19,31-33]. This goal can be realized with the engagement of volunteers. Thus, it is achieved through the volunteers' engagements, who contribute their time and effort to collect food from supermarkets and distribute it among people. In this sense, their engagement is key to reducing food wastage. Realization also depends on the extent to which the organization is able to recruit and retain volunteers as members. The engagement of volunteers is incentivized through the possibilities to contribute to a societal goal, the belonging to a group of people sharing interests and through receiving food for free in exchange. Previous research on volunteer engagement already emphasizes that volunteers weigh up the costs and benefits of volunteering [12-15]. As motives, selfand other-interest were, in particular, differentiated; focusing either on altruistic or egoistic motives. The volunteer-organization work relationship is dynamic and stable, so long as the volunteer and organizational perspectives are balanced.

\subsection{Conceptual Contributions}

This paper makes three conceptual contributions. First and foremost, the study emphasizes that altruistic and egoistic motives of volunteers occur simultaneously. It was striking that it is important to volunteers to gain not only "intangible benefits" [45] such as being part in reducing food wastage and networking but also tangible benefits, such as food. The analysis reveals that volunteers engage in the organization to contribute to the societal goal of reducing food wastage (ecological motive), to meet like-minded people (social motive) and to receive free food (economic motive) [31-33]. Ecological and social motives refer to the interest in others [4], i.e., reducing food wastage; economic motives refer especially to the self-interest of receiving food. Consequently, the case selected reveals the simultaneous occurrence of interests [4]. Moreover, egoistic self-interest and 
altruistic other-interest merge when the consumption of food promotes the reduction of food wastage.

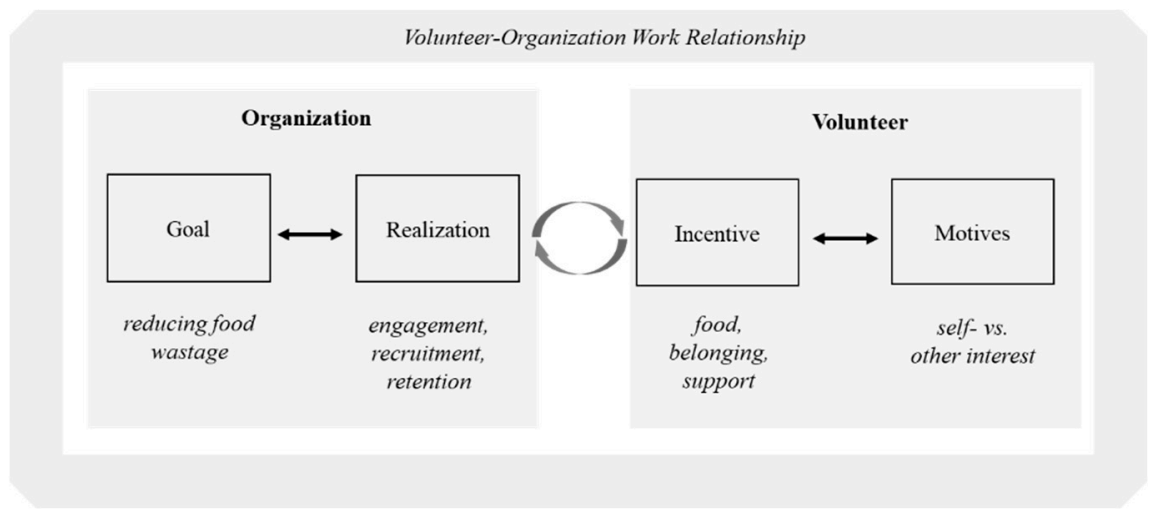

Figure 2. Volunteer-Organization Work Relationship.

Second, the study illustrates how the individual and the organizational level are interrelated. We already know that volunteers weigh up the costs and benefits of volunteering [12]. More concretely, volunteers participate in the organization to receive food in exchange. As long as they have the opportunity to collect food and to pursue their self-interest, they engage with and for the organization. The relationship between volunteers and organizations can, thus, be understood as exchange relationship based on reciprocity $[4,5]$. However, the digital mode of organizing engagement resulting in a specific interrelation of the organization and (more or less) self-organized individuals results in paradoxes and problems on the organizational level. This could even endanger the achievement of organizational and societal goals, e.g., when certain tasks are not undertaken, such as tasks necessary for the highly regulated food safety sector, for example, the cleaning of and caring for local spots. As a result, the nonprofit organization depends especially on the simultaneous fulfillment of individual and organizational interests.

Third, the study also contributes to understanding organizing volunteer engagement with the help of digital technologies [16-22]. The use of online platforms and apps results in the possibility for volunteers to self-organize their engagement. This is successful regarding the large number of volunteers engaged and the amount of achievements. With the help of digital technologies, nonprofit organizations also promote the realization of a new mode of volunteer work. Consequently, a structural change in volunteer work can be observed, which is accompanied by the volunteers' flexibility and autonomy, e.g., with regard to the amount of time, scheduling and the engagement's duration [46]. This surely also involves weighing up the costs, such as physical resources and time, and the benefits of volunteering, in terms of meeting interests and needs, as a basis for the decision to volunteer [12-15].

\subsection{Practical Implications}

Based on the findings of the case study investigated, practical implications can also be derived. The case investigated reveals that digital nonprofit organizations have the potential to motivate a large number of people to engage for societal aims. This is based on the low-threshold to participate and the autonomous and flexible self-organization that is provided through the use of digital technologies. This could also be relevant for other nonprofit organizations. However, digital nonprofit organizations need to consider the alignment of individual motives and organizational goals. In this sense, they have to make sure that the volunteers' self-interests are satisfied when they want to recruit and retain them. Thus, to promote the volunteers' engagement, it is essential that they have the opportunity to self-organize their engagement, with the help of digital technologies providing the flexibility to do so. Moreover, to meet the needs of volunteers, enough possibilities to engage in the good cause and the ability to receive goods in exchange are required to secure the positive effect of following egoistic motives. Finally, it is recommended to 
explain extensively and vehemently why certain tasks are necessary. Another option could also be to incentivize tasks that do not typically directly benefit individuals, as they are instead addressing altruistic motives and other-interest. It could also be mandatory for volunteers to take over these tasks to stay a member. More positively, volunteers could also be motivated with receiving options for attractive engagements by implementing a gamification approach.

\subsection{Limitations and Perspectives for Further Research}

The limitations of the study are the following. First, although the case study provides insights into a certain field, the samples of the qualitative as well as the online study are highly specific and comparatively small. The sample could be expanded in future studies, e.g., with regard to the role of consumers or an international comparison, since similar organizations also exist in other countries. Second, by using the case selected as a dynamic and fast-growing organization, the findings relate to a specific field and a certain time. Future studies should attempt to replicate the results in other nondigital nonprofit settings to further investigate the relation of altruistic and egoistic motives in volunteering and also to estimate how technologies change social interactions between individuals. Third, it could be also worth comparing non- and for-profit settings since (a) we find similarly digitally organized for-profit platform organizations [47], and (b) classic organizations are expected to pursue the societal goal of sustainability. In this context, other food initiatives such as OLIO or Too Good to Go are of interest. Eventually, this would help to investigate the relevance of the altruistic other-interests and egoistic self-interests of workers in other fields.

Funding: This research received no external funding.

Institutional Review Board Statement: Ethical review and approval were waived for this study since it is based on interviews and surveys that were voluntary with the option to cancel; and anonymity was assured.

Informed Consent Statement: Informed consent was obtained from all subjects involved in the study.

Data Availability Statement: The data presented in this study are available on request from the corresponding author.

Conflicts of Interest: The author declares no conflict of interest.

\section{Appendix A}

Table A1. Sample of Organizational Representatives.

\begin{tabular}{|c|c|c|c|c|c|c|c|c|}
\hline & O1 & $\mathrm{O} 2$ & O3 & O4 & O5 & O6 & O7 & O8 \\
\hline Gender & F & M & M & $\mathrm{F}$ & M & $\mathrm{F}$ & M & F \\
\hline $\begin{array}{c}\text { Year of } \\
\text { birth }\end{array}$ & 1989 & 1963 & 1962 & 1981 & 1968 & 1982 & 1985 & 1991 \\
\hline Function & $\begin{array}{c}\text { Am- } \\
\text { bassador }\end{array}$ & $\begin{array}{c}\text { Board } \\
\text { member }\end{array}$ & $\begin{array}{l}\text { Board } \\
\text { member }\end{array}$ & $\begin{array}{c}\text { Am- } \\
\text { bassador }\end{array}$ & $\begin{array}{c}\text { Am- } \\
\text { bassador }\end{array}$ & $\begin{array}{c}\text { Am- } \\
\text { bassador }\end{array}$ & $\begin{array}{c}\text { Task Force } \\
\text { Leader }\end{array}$ & $\begin{array}{c}\text { Task Force } \\
\text { Leader }\end{array}$ \\
\hline $\begin{array}{c}\text { Final } \\
\text { degree }\end{array}$ & $\begin{array}{l}\text { Master } \\
\text { degree }\end{array}$ & $\begin{array}{l}\text { Master } \\
\text { degree }\end{array}$ & $\begin{array}{l}\text { Master } \\
\text { degree }\end{array}$ & $\begin{array}{l}\text { Master } \\
\text { degree }\end{array}$ & Education & Education & $\begin{array}{l}\text { Restaurant } \\
\text { specialist }\end{array}$ & Bachelor \\
\hline Occupation & Student & $\begin{array}{l}\text { Freelance } \\
\text { journalist }\end{array}$ & $\begin{array}{l}\text { Freelance } \\
\text { journalist }\end{array}$ & $\begin{array}{l}\text { Translator } \\
\text { and coach }\end{array}$ & $\begin{array}{c}\text { Un- } \\
\text { employed }\end{array}$ & $\begin{array}{c}\text { Office } \\
\text { worker }\end{array}$ & $\begin{array}{c}\text { Office } \\
\text { worker }\end{array}$ & Student \\
\hline $\begin{array}{c}\text { Engaged } \\
\text { since }\end{array}$ & 2015 & 2012 & 2012 & 2014 & 2015 & 2014 & 2015 & 2014 \\
\hline
\end{tabular}


Table A2. Sample of Volunteers.

\begin{tabular}{|c|c|c|c|c|c|c|c|}
\hline & V1 & V2 & V3 & V4 & V5 & V6 & V7 \\
\hline Gender & $\mathrm{M}$ & $\mathrm{F}$ & $M$ & $\mathrm{~F}$ & $\mathrm{~F}$ & $M$ & $M$ \\
\hline Year of birth & 1988 & 1992 & 1987 & 1983 & 1992 & 1990 & 1988 \\
\hline Function & Food-saver & Food-sharer & Food-sharer & Food-saver & Food-saver & $\begin{array}{l}\text { Responsible } \\
\text { person }\end{array}$ & $\begin{array}{l}\text { Food- } \\
\text { saver }\end{array}$ \\
\hline Final degree & $\begin{array}{l}\text { Bachelor } \\
\text { degree }\end{array}$ & $\begin{array}{c}\text { Bachelor } \\
\text { degree }\end{array}$ & $\begin{array}{c}\text { Bachelor } \\
\text { degree }\end{array}$ & $\begin{array}{l}\text { Master } \\
\text { degree }\end{array}$ & $\begin{array}{c}\text { Bachelor } \\
\text { degree }\end{array}$ & $\begin{array}{c}\text { Bachelor } \\
\text { degree }\end{array}$ & $\begin{array}{c}\text { Bachelor } \\
\text { degree }\end{array}$ \\
\hline Occupation & Student & Student & Student & Office worker & Student & Student & Student \\
\hline $\begin{array}{l}\text { Engaged } \\
\text { since }\end{array}$ & 2016 & 2016 & 2009 & 2016 & 2015 & 2013 & 2015 \\
\hline
\end{tabular}

\section{References}

1. Baglioni, S.; De Pieri, B.; Tallarico, T. Surplus food recovery and food aid: The pivotal role of non-profit organisations. Insights from Italy and Germany. VOLUNTAS: Int. J. Volunt. Nonprofit Organ. 2017, 28, 2032-2052.

2. Cox, J.; Oh, E.Y.; Simmons, B.; Graham, G.; Greenhill, A.; Lintott, C.; Masters, K.; Woodcock, J. Doing good online: The changing relationships between motivations, activity, and retention among online volunteers. Nonprofit Volunt. Sect. Q. 2018, 47, 1031-1056. [CrossRef]

3. Harp, E.R.; Scherer, L.L.; Allen, J.A. Volunteer engagement and retention: Their relationship to community service self-efficacy. Nonprofit Volunt. Sect. Q. 2017, 46, 442-458. [CrossRef]

4. Godbout, J.T.; Caille, A.C. World of the Gift; McGill-Queen's Press: Montreal, QC, Canada; Kingston, ON, Canada, 1998.

5. Mauss, M. The Gift: The Form and Reason for Exchange in Archaic Societies; Routledge: London, UK, 2002.

6. Schulz-Schaeffer, I. Crowdsupporting als Gabentausch. Zur soziologischen Analyse des Crowdfunding. Kölner Z. Soziologie Und Soz. 2017, 69, 27-50. [CrossRef]

7. Yin, R.K. Case Study Research. Design and Methods; Sage: Thousand Oaks, CA, USA, 2014.

8. Agostinho, D.; Paço, A. Analysis of the motivations, generativity and demographics of the food bank volunteer. Int. J. Nonprofit Volunt. Sect. Mark. 2012, 17, 249-261. [CrossRef]

9. Wilson, J. Volunteering. Annu. Rev. Sociol. 2000, 26, 215-240. [CrossRef]

10. MacNeela, P. The give and take of volunteering: Motives, benefits, and personal connections among Irish volunteers. Volunt. Int. J. Volunt. Nonprofit Organ. 2008, 19, 125-139. [CrossRef]

11. Schervish, P.G. The dependent variable of the independent sector: The definition and measurement of giving and volunteering. Volunt. Int. J. Volunt. Nonprofit Organ. 1993, 4, 223-232. [CrossRef]

12. McAllum, K. Meanings of organizational volunteering: Diverse volunteer pathways. Manag. Commun. Q. 2014, 28, 84-110. [CrossRef]

13. Davis, M.H.; Hall, J.A.; Meyer, M. The first year: Influences on the satisfaction, involvement, and persistence of new community volunteers. Personal. Soc. Psychol. Bull. 2003, 29, 248-260. [CrossRef] [PubMed]

14. Sundeen, R.A.; Raskoff, S.A.; Garcia, M.C. Differences in perceived barriers to volunteering to formal organizations: Lack of time versus lack of interest. Nonprofit Manag. Leadersh. 2007, 17, 279-300. [CrossRef]

15. Shye, S. The motivation to volunteer: A systemic quality of life theory. Soc. Indic. Res. 2010, 98, 183-200. [CrossRef]

16. Davies, A.R.; Cretella, A.; Franck, V. Food sharing initiatives and food democracy: Practice and policy in three European cities. Politics Gov. 2019, 7, 8-20. [CrossRef]

17. Harvey, J.; Smith, A.; Goulding, J.; Illodo, I.B. Food sharing, redistribution, and waste reduction via mobile applications: A social network analysis. Ind. Mark. Manag. 2019, 88, 437-448. [CrossRef]

18. Makov, T.; Shepon, A.; Krones, J.; Gupta, C.; Chertow, M. Social and environmental analysis of food waste abatement via the peer-to-peer sharing economy. Nat. Commun. 2020, 11, 108. [CrossRef]

19. Michelini, L.; Principato, L.; Iasevoli, G. Understanding food sharing models to tackle sustainability challenges. Ecol. Econ. 2018, 145, 205-217. [CrossRef]

20. Michelini, L.; Grieco, C.; Ciulli, F.; Di Leo, A. Uncovering the impact of food sharing platform business models: A theory of change approach. Br. Food J. 2020, 122, 1437-1462. [CrossRef]

21. Morrow, O. Community self-organizing and the urban food commons in Berlin and New York. Sustainability $2019,11,3641$. [CrossRef]

22. Morrow, O. Sharing food and risk in Berlin's urban food commons. Geoforum 2019, 99, 202-212. [CrossRef]

23. Cnaan, R.A.; Goldberg-Glen, R.S. Measuring motivation to volunteer in human services. J. Appl. Behav. Sci. 1991, 27, 269-284. [CrossRef]

24. Clary, E.G.; Snyder, M.; Stukas, A.A. Volunteers' motivations: Findings from a national survey. Nonprofit Volunt. Sect. Q. 1996, 25, 485-505. [CrossRef]

25. Stukas, A.A.; Hoye, R.; Nicholson, M.; Brown, K.M.; Aisbett, L. Motivations to volunteer and their associations with volunteers' well-being. Nonprofit Volunt. Sect. Q. 2016, 45, 112-132. [CrossRef] 
26. Sokolowski, S.W. Show me the way to the next worthy deed: Towards a microstructural theory of volunteering and giving. VOLUNTAS Int. J. Volunt. Nonprofit Organ. 1996, 7, 259-278. [CrossRef]

27. FAO. Food Loss and Food Waste. 2017. Available online: www.fao.org/food-loss-and-food-waste/en/ (accessed on 30 October 2021).

28. Guyader, H. No one rides for free! Three styles of collaborative consumption. J. Serv. Mark. 2018, 32, 692-714.

29. Gollnhofer, J.F.; Weijo, H.A.; Schouten, J.W. Consumer movements and value regimes: Fighting food waste in Germany by building alternative object pathways. J. Consum. Res. 2019, 46, 460-482. [CrossRef]

30. Gollnhofer, J. Normalizing alternative practices: The recovery, distribution and consumption of food waste. J. Mark. Manag. 2017, 33, 624-643. [CrossRef]

31. Ganglbauer, E.; Fitzpatrick, G.; Subasi, Ö.; Güldenpfennig, F. Think Globally, Act Locally: A Case Study of a Free Food Sharing Community and Social Networking; ACM: Baltimore, MD, USA, 2014; pp. 911-921.

32. Rombach, M.; Bitsch, V. Food movements in Germany: Slow food, food sharing, and dumpster diving. Int. Food Agribus. Manag. Rev. 2015, 18, 1-24.

33. Schanes, K.; Stagl, S. Food waste fighters: What motivates people to engage in food sharing? J. Clean. Prod. 2019, $211,1491-1501$. [CrossRef]

34. Creswell, J.W.; Plano Clark, V.L.; Gutmann, M.L.; Hanson, W.E. Advanced mixed methods research designs. In Handbook of Mixed Methods in Social and Behavioral Research; Tashakkori, A., Teddlie, C., Eds.; Sage: Thousand Oaks, CA, USA, 2003 ; pp. $209-240$.

35. Foodsharing. Food Sharing. Share Food Instead of Wasting It. 2021. Available online: https:/ / foodsharing.de/ (accessed on 30 October 2021).

36. Pina e Cunha, M.; Cabral-Cardoso, C.; Clegg, S. Manna from heaven: The exuberance of food as a topic for research in management and organization. Hum. Relat. 2008, 61, 935-963. [CrossRef]

37. Figueroa, S.K. The grounded theory and the analysis of audio-visual texts. Int. J. Soc. Res. Methodol. 2008, 11, 1-12. [CrossRef]

38. Emerson, R.M.; Fretz, R.I.; Shaw, L.L. Participant observation and fieldnotes. In Handbook of Ethnography; Atkinson, P., Coffey, A., Delamont, S., Lofland, J., Lofland, L., Eds.; Sage: Thousand Oaks, CA, USA, 2001; pp. 352-368.

39. Mayring, P. Qualitative Content Analysis; Qualitative Social Research 2000. Available online: http:/ /www.qualitative-research. net/index.php/fqs/article/view/1089/2385 (accessed on 30 October 2021).

40. Breaugh, J.A. The measurement of work autonomy. Hum. Relat. 1985, 38, 551-570. [CrossRef]

41. Ryan, R.M.; Deci, E.L. Self-determination theory and the facilitation of intrinsic motivation, social development and well-being. Am. Psychol. 2000, 55, 68-78. [CrossRef] [PubMed]

42. Rich, B.L.; LePine, J.A.; Crawford, E.R. Job engagement: Antecedents and effects on job performance. Acad. Manag. J. 2010, 53, 617-635. [CrossRef]

43. Olson, M. The Logic of Collective Action, Public Goods and the Theory of Groups; Harvard University Press: Cambridge, MA, USA, 1965.

44. Botsman, R.; Rogers, R. What's Mine is Yours: The Rise of Collaborative Consumption; Harper Collins: New York, NY, USA, 2011.

45. Bekkers, R.; Wiepking, P. A literature review of empirical studies of philanthropy: Eight mechanisms that drive charitable giving. Nonprofit Volunt. Sect. Q. 2011, 40, 924-973. [CrossRef]

46. Farmer, S.M.; Fedor, D.B. Volunteer participation and withdrawal. Nonprofit Manag. Leadersh. 1999, 9, 349-368. [CrossRef]

47. Baptista, J.; Stein, M.-K.; Klein, S.; Watson-Manheim, M.B.; Lee, J. Digital work and organisational transformation: Emergent Digital/Human work configurations in modern organisations. J. Strateg. Inf. Syst. 2020, 29, 101618. [CrossRef] 